CATALLAXY

Volume 5 Issue 2 December 2020

e-ISSN 2544-090X

¿ www.catallaxy.pl

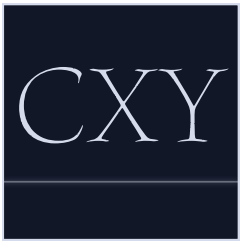

Oryginalny artykut naukowy

received: 10.11 .2020 / accepted: 15.12 .2020 / published online: 31.12 .2020

Sokołowska, A. (2020). System gwarantowania depozytów w Unii Europejskiej. Catallaxy, 5(2): 97-105. doi:10.24136/ cxy.2020.009.

\title{
System gwarantowania depozytów w Unii Europejskiej
}

\author{
AGNIESZKA SOKOEOWSKA \\ Uniwersytet Pedagogiczny im. KEN w Krakowie, Instytut Prawa i Ekonomii, ul. Podchorążch 2, 30-082 Kraków, Polska \\ $\square$ agnieszka.sokolowska@student.up.krakow.pl \\ (iD) orcid.org/0000-0003-1118-010X
}

\begin{abstract}
Abstrakt
Motywacja: W literaturze przedmiotu można odnaleźć wiele informacji na temat unii bankowej. Brakuje jednak wskazania na cechy europejskiego systemu gwarantowania depozytów z uwzględnieniem zmian po 2017 r.

Cel: Celem artykułu jest ukazanie problematyki systemu gwarantowania depozytów w Unii Europejkkiej uwzględniając systemy gwarantowania depozytów w państwach członkowskich. Opisano jego założenia, etapy wprowadzenia. Omówiono także nową reformę, która była spowodowana brakiem terminowości realizacji pierwotnych założeń poszczególnych etapów oraz jej zmiany. Zawarto również podstawowe informacje o Bankowym Funduszu Gwarancyjnym (BFG). Materiały i metody: Wykorzystano krytyczną analizę literatury przedmiotu przy niewielkim wsparciu analizą statystyczną. Materiał empiryczny stanowią dane BFG oraz dane zamieszczone w publikacjach.

Wyniki: Europejski system gwarantowania depozytów wydaje się być koniecznym w celu budowy pełnej unii bankowej i doprowadzenia do zwiększenia integracji państw strefy euro. Utworzenie europejskiego systemu gwarantowania depozytów wzmocni ochronę deponentów, ponieważ odtąd odpowiedzialność zostanie przeniesiona na poziom europejski.
\end{abstract}

Stowa kluczowe: europejski system gwarantowania depozytów; Bankowy Fundusz Gwarancyjny; unia bankowa JEL: G21; G28; G29; G33

\section{Wprowadzenie}

Mimo, że systemy gwarantowania depozytów nie mają długiego rodowodu, to są obecne aktualnie $w$ większości systemów bankowych. Jest to nieodłączny element budowania sieci bezpieczeństwa państwa. Kryzysy, jakie miały miejsce w sektorze bankowym były bodźcem do podjęcia prac przez Unię Europejską (UE) w ramach procesów integracyjnych. Rozpoczęto działania nad wprowadzeniem jednolitej regulacji prawnej systemów gwarantowania depozytów. W związku z tym w 2012 r. zaprojektowano jako jeden $z$ filarów unii bankowej - europejski system gwarantowania depozytów (European deposit insurance scheme, EDIS). Instytucja ta miała zapewnić zwiększenie stabilności waluty euro, systemu finansowego i doprowadzić do ogólnego wzrostu zaufania do banków w państwach euro (Lipiński, 2019). Celem artykułu jest ukazanie problematyki systemu gwarantowania depozytów w UE i jej państw członkowskich (ze szczególnym uwzględnieniem Polski) jego założeń, etapów wprowadzenia, a także nowej reformy, która była spowodowana brakiem terminowości realizacji pierwotnych założeń poszczególnych etapów oraz jej zmian i omó- 
wienie Bankowego Funduszu Gwarancyjnego (BFG).

W Sekcji 2. dokonano przegląd literatury pomiotu. W Sekcji 3. wyróżniono wykorzystane materiały i metody. W Sekcji 4. omówiono wyniki, a w Sekcji 5. zawarto podsumowanie przeprowadzonej analizy.

\section{Przegląd literatury}

System gwarantowania depozytów jest jednym z elementów sieci bezpieczeństwa finansowego. W opinii laureata Nagrody Banku Szwecji im. Alfreda Nobla w dziedzinie ekonomii E. Stiglitza, każdy idealny system bankowy funkcjonujący $w$ obecnych czasach powinien posiadać system gwarantowania depozytów (Małecka i Włodarczyk, 2012).

Sięgając do początków systemów gwarantowania depozytów, należy wspomnieć, że tworzyły się one jako odpowiedź na istniejące kryzysy systemów bankowych. Wielki kryzys gospodarczym z 1933 r. skutkowal utworzeniem pierwszego sformalizowanego systemu gwarantowania depozytów. Miało to miejsce w Stanach Zjednoczonych. Warto wspomnieć, że przed wybuchem kryzysu finansowego w 2007 r., rynki finansowe charakteryzowały się coraz większą integracją i współzależnością i to nie tylko w UE, ale i na całym świecie. Wybuch kryzysu finansowego zatrzymał ten proces, a powodem był spadek transgranicznych przepływów finansowych. W związku z tym, w ramach pomocy w okresie od października 2008 r. do października 2011 r., Komisja zatwierdziła środki pomocy państwa na kwotę 4,5 bln euro (Komisja Europejska, 2012). Ujawniło to potrzebę natychmiastowej reformy sektora usług finansowych. UE przyjęła własne reformy, które za zadanie miały realizację wieloletnich celów, np. zakończenie budowy jednolitego rynku. Od momentu rozpoczęcia kryzysu Komisja przedstawiła ponad pięćdziesiąt inicjatyw UE takich, jak unia bankowa czy tez unia rynków kapitałowych. Wszystkie te reformy (tzw. pokryzysowe) przyniosły pewien stopień centralizacji. Były przyczyną przeniesienia odpowiedzialności za wiele aspektów regulacji i nadzoru usług finansowych ze szczebla krajowego na szczebel UE (Parlament Europejski, 2020).

Obecnie systemy takie występują we wszystkich państwach członkowskich UE, a także w państwach wysokorozwiniętych. Nie wyklucza to istnienia systemów gwarantowania depozytów w państwach niskorozwiniętych, a najlepszym przykładem będzie Kenia, Kongo czy też Uganda (Pawlikowski, 2005). Wielki kryzys gospodarczy ukazał jak ogromny i negatywny wpływ ma kryzys finansowy na gospodarkę. W celu przeciwdziałania postępującej destabilizacji gospodarki, powołano Federal Deposit Insurance Corporation (Małecka i Włodarczyk, 2012). To organizacja, która jest najdłużej istniejącą instytucją gwarantującą depozyty bankowe na świecie. Zasięg, jaki posiada, obejmuje nie tylko banki należące do systemu Rezerwy Federalnej, ale i banki stanowe, które dobrowolnie przystąpiły do systemu (Szczepańska, 2005). Instytucja ta przyczynia się w ogromnej mierze do utrzymywania stabilności finansowej. Jest ona przykładem działalności wykorzystującej system risk minimizer. Na przestrzeni lat, instytucja rozwijała się dostosowując się do aktualnej sytuacji panującej w danym czasie w sektorze bankowym (Małecka i Włodarczyk, 2012). W Stanach Zjednoczonych bardzo długo funkcjonowały gwarancje stanowe. W momencie, gdy zaprzestały swojej działalności, w 1907 r. podjęto kolejną próbę wprowadzenia systemów gwarantowania depozytów. Swoją działalność oparły o jednodziałowe banki. Jednak z powodów strat, na które wpływ miał kryzys rolny w latach 20. XX wieku, doprowadziło to do ich bankructwa (Małecka i Włodarczyk, 2012).

Dla Polski przełomowym był 1994 r., kiedy to przyjęto Dyrektywę 94/19/WE w sprawie systemów gwarancji depozytów (1994), a także sformalizowano polski system gwarantowania depozytów Ustawą o Bankowym Funduszu Gwarancyjnym (1994). Europejskie przepisy regulują tylko działalność gwarancyjną, natomiast polska ustawa reguluje powyższą kwestię obszerniej, odnosząc się nie tylko do działalności gwarancyjnej, ale i do 
działalności pomocowej, prowadzonej przez BFG. Dyrektywa 94/19/WE (1994) wymusiła na państwach członkowskich UE konieczność utworzenia i uznania na własnym terytorium jednego lub nawet kilku systemów gwarantowania środków pieniężnych $\mathrm{w}$ instytucjach kredytowych. Dyrektywa 94/19/WE (1994) zawiera generalne zasady gwarantowania depozytów, a także kryteria przynależności do systemu, zakres ochrony oraz warunki i terminy ubiegania się klientów o wypłatę świadczeń gwarancyjnych (Dunaszewska, 2009).

Kwestie tworzenia systemu gwarantowania depozytów na świecie pokrótce omówiono. Niniejszy artykuł koncentruje się na UE i jej państwach członkowskich, w związku z czym konieczne jest omówienie kwestii ewolucji systemu gwarantowania depozytów w UE.

Początki gwarantowania depozytów na obszarze obecnej UE sięgają 20. XX wieku. Czechosłowacja $\mathrm{w}$ tamtych czasach wyprzedzała inne systemy, istniejące już formalnie od ponad 40 lat (Litan, 2007, s. 26). Lata 60., 70. i 80. przyczyniły się do rozpoczęcia prac nad stworzeniem systemów gwarantowania depozytów. Państwa wysoko rozwinięte, w tym: Niemcy, Finlandia, Belgia, Hiszpania, Holandia, Austria, Wielka Brytania i Francja, jako jedne $z$ pierwszych wprowadziły systemy gwarantowania depozytów. Ten pierwszy etap trwał do 1986 r. (Małecka i Włodarczyk, 2012, s. 525). Ważnym elementem było to, że wszystkie te systemy łączył wspólny element: zabezpieczenie depozytów w bankach krajowych. Wiązało się to $z$ tym, że nie dotyczyło to depozytów w oddziałach zagranicznych. Komisja Europejska Zaleceniem 87/63/EWG (1986) podjęła pierwsze stanowisko $\mathrm{w}$ sprawie gwarantowania depozytów. Zawarła tam przede wszystkim cztery zasady funkcjonowania systemów gwarancyjnych w państwach UE:

- gwarantowanie wypłat depozytów dla deponentów;

- zapewnienie ochrony deponentów wszystkich instytucji, które przyjmują depozyty;

- umiejętność rozdziału interwencji podejmowanych przed ogłoszeniem nie- wypłacalności instytucji kredytowej, $z$ wypłatami gwarantowanymi po jej upadłości;

- przejrzystość i zrozumiałość zasad odnoszących się do wypłat środków gwarantowanych.

Problem, jaki wiąże się z tymi zaleceniami polegał na braku wiążącego charakteru, co doprowadziło do mozaiki form wprowadzanych systemów $w$ państwach członkowskich UE. Kolejnym krokiem było podjęcie działań dążących do zharmonizowania systemów gwarancji depozytów $w$ państwach należących do UE. Uczyniono to Dyrektywą 94/19/WE (1994), którą następnie zmieniono kolejną Dyrektywą 2009/14/WE (2009). Dyrektywa 2009/14/WE (2009) wprowadziła m.in. stały poziom gwarancji depozytów w UE, który wynosi 100000 euro. W ramach istniejących w UE systemów krajowych, system gwarancji depozytów, który dokonuje płatności gwarantowanych $w$ ramach tych systemów jest upoważniony, w ramach postępowania likwidacyjnego lub reorganizacyjnego, do wejścia w prawa deponentów, lecz tylko do pewnego stopnia, a mianowicie do wysokości dokonanych przez nich wpłat. W odniesieniu do płatności $\mathrm{w}$ postępowaniu restrukturyzacyjnym i likwidacyjnym system depozytów ma prawo rościć w stosunku do danej instytucji kredytowej do wysokości kwoty dokonanych przez niego płatności.

\section{Materiały i metody}

Jako metodę badawczą wybrano krytyczną analizę literatury przedmiotu przy niewielkim wsparciu analizą statystyczną. Materiał empiryczny stanowią dane BFG (2019) oraz dane zamieszczone w publikacjach.

Analiza źródeł naukowych umożliwiła wyciągnięcie wniosków w oparciu o krajowe i zagraniczne publikacje naukowe dotyczące tematyki systemu depozytów bankowych. Analiza statystyk umożliwiła określenie zmian na płaszczyźnie funduszy własnych BFG. 
4. Wyniki badania

4.1. Analiza systemu gwarantowania depozytów w Unii Europejskiej na przykładzie Bankowego Funduszu Gwarancyjnego

BFG jest instytucją, która gwarantuje depozyty $\mathrm{w}$ Polsce prowadząc kilka rodzajów działalności. Przede wszystkim gwarantuje depozyty, ale i odpowiedzialna jest za pomoc wobec uczestniczących w systemie, jak i realizuje inne zadania, które są następujące (Florczak, 2015):

- prowadzi działalność analityczną;

- nadzoruje system gwarantowania depozytów;

- prowadzi działalność pomocową;

- gwarantuje depozyty;

- wykonuje działalność kontrolną.

BFG jest finansowany $z$ funduszy typu $e x$ post, które powstają przez wpłaty uczestników systemu po uprzednim spełnieniu warunków gwarancji, a także funduszy typu ex ante, które są niczym innym jak dostępnymi funduszami własnymi BFG, których źródło leży w obowiązkowych wpłatach uczestników systemu.

BFG w specyficznej kolejności uruchamia wypłaty sum gwarantowanych. Jako pierwsze zostają wypłacone środki z funduszu ochrony środków gwarantowanych, a następnie środki z funduszy własnych BFG. W ciągu zaledwie kilku lat można zauważyć wzrost stawek na fundusz ochrony środków gwarantowanych. Jest to spowodowane upadłościami niektórych uczestników systemu i wynikającej $z$ umowy konieczności wypłaty sum gwarantowanych.

Pod koniec 2019 r. objęto ochroną gwarancyjną depozyty zgromadzone we wszystkich bankach, nie dotyczy to jednak Banku Gospodarstwa Krajowego (BGK) i banków hipotecznych, a także wszystkich kas oszczędnościowo-kredytowych. W raporcie BFG (2019) wyróżnia wyłączonych dwadzieścia dziewięć banków komercyjnych i 538 banki spółdzielcze, a także dwadzieścia pięć kas oszczęnościowo-kredytowych. Gwarancja dotyczy środków od dnia ich wniesienia na rachunek, nie może to nastąpić później niż $\mathrm{w}$ dniu poprzedzającym dzień spełnienia warunku gwarancji - do wysokości równowartości 100000 euro. Istnieją jednak szczególne warunki gwarancji, o których stanowi art. 24 ust. 3 i 4 Ustawy o Bankowym Funduszu Gwarancyjnym (1994). Środki deponenta przekraczające 100000 euro mogą zostać objęte gwarancjami w terminie 3 miesięcy od dnia ich wpływu na rachunek lub powstania należności (BGK, 2019).

Ustawę o zmianie ustawy o Bankowym Funduszu Gwarancyjnym, systemie gwarantowania depozytów oraz przymusowej restrukturyzacji oraz niektórych innych ustaw (2019) znowelizowano 7 marca 2019 r. Ustawą wyłączono $z$ udziału $w$ systemie gwarantowania depozytów banki hipoteczne. Dodatkowo katalog deponentów uzupełniono o rady rodziców, co wiąże się z objęciem ochroną gwarancyjną środków na rachunkach bankowych, prowadzonych dla rad rodziców (BGK, 2019).

Minister Finansów w Rozporządzeniu w sprawie zawieszania wypłaty środków gwarantowanych deponentom w przypadku blokady środków zdeponowanych na rachunku (2019) uwzględnił wprowadzenie w 2018 r. do polskiego porządku prawnego blokady rachunku podmiotu kwalifikowanego w rozumieniu Ustawy ordynacja podatkowa (1997). Skutkowało to tym, że blokada rachunku podmiotu, wobec którego nastąpiło spełnienie warunku gwarancji, zawiesza wypłatę środków gwarantowanych (BGK, 2019).

Lata 2007-2009 i tym samym kryzys finansowy o charakterze globalnym wysunął propozycję udoskonalenia europejskich ram gwarantowania depozytów (Boccuzzi, 2016).

Dyrektywa 2014/49/UE (2014) wprowadziła zmiany do Dyrektywy 94/19/WE (1994). Dotyczyły one sposobów działania krajowych instytucji gwarancji depozytów w celu zwiększenia stabilizacji, a także ochrony europejskich deponentów. Dzięki tej dyrektywie obszar ten ujednolicono. Dyrektywą 2014/49/UE (2014) zastosowano rozwiązania według zasady maksymalnej harmonizacji, opozycyjnie do Dyrektywy 94/19/ 
WE (1994), w której odwołano się do mechanizmów minimalnej harmonizacji (Ognjenovic, 2017). Wiązało się to $z$ istnieniem wielu rodzajów systemów gwarancji depozytów tak mocno różniących się od siebie. Wdrożenie wymogów, które swoim zakresem obejmują wspólnie państwa członkowskie może spowodować eliminację zakłóceń na rynku. Dyrektywa 2014/49/UE (2014) przyczynia się zatem do urzeczywistnienia rynku wewnętrznego. Głównym jej celem było usunięcie różnic, jakie występowały $\mathrm{w}$ ustawodawstwach państw członkowskich $\mathrm{w}$ odniesieniu do przepisów dotyczących systemów gwarancji depozytów, którym podlegają te instytucje kredytowe. Wdrożenie Dyrektywy 2014/49/ UE (2014) pozwoliło ograniczyć różnice $\mathrm{w}$ zasadach funkcjonowania poszczególnych systemów występujących w państwach członkowskich, co miało zapewnić wysoki poziom ochrony depozytów. Dyrektywa 2014/49/ UE (2014) miała zagwarantować jednolity poziom ochrony przy zachowaniu jednakowej stabilności systemów gwarancji depozytów dla deponentów (Ognjenovic, 2017).

\subsection{Harmonizacja systemów gwarantowania depozytów w państwach członkowskich EU: europejski system gwarantowania depozytów}

Dyrektywa 2014/49/UE (2014) w swojej treści umieszcza zasady, jakimi powinien charakteryzować się zharmonizowany system. Są one następujące (Jurkowska, 2018):

- utrzymanie kwot gwarancyjnych w wysokości 100000 euro;

- skrócenie terminu wypłat do 7 dni roboczych;

- ustalenie jednolitego minimalnego poziomu docelowego ex ante środków finansowych na systemie gwarancji depozytów (system for deposit guarantee schemes, DGS) na $0,8 \%$ kwoty gwarantowanych depozytów, posiadanych przez instytucje będące uczestnikami danego systemu;

- możliwość udzielania pożyczek między systemami gwarantowania depozytów na zasadzie dobrowolności.
Utrzymanie kwot gwarancyjnych w wysokości 100000 euro ma na celu usunięcie problemów występujących na rynku $z$ powodu różnicowania poziomu gwarancji w poszczególnych państwach członkowskich. Mogłoby to wiązać się z niebezpieczeństwem przenoszenia przez deponentów środków finansowych do banków, które mają siedziby w państwach, gdzie poziom gwarancji dla depozytów jest wyższy (Cariboni i in., 2008).

Co ważne, 24 listopada 2015 r. Komisja Europejska w sprawie rozporządzenia Parlamentu Europejskiego i Rady w swoim Wniosku (2014) zaplanowała utworzenie trzeciego filaru unii bankowej, którym ma być europejski system gwarantowania depozytów EDIS. Ma to nastąpić przez zmianę Rozporządzenia nr 806/2014 (2014). EDIS ma bazować na systemie wypracowanym już w Dyrektywie 2014/49/UE (2014), ale ma on stanowić rozszerzenie dotychczasowej konstrukcji zharmonizowanych krajowych systemów gwarantowania depozytów. Dodatkowo ma on zapewnić deponentom indywidualnym jednakowy poziom ochrony. W ciągu 8 lat instytucja ta przejmie wykonywanie zadań gwarantowania depozytów w państwach, które biorą udział $\mathrm{w}$ unii bankowej. W związku $z$ tym, program ten byłby obligatoryjny dla państw członkowskich strefy euro, a także fakultatywnie objąłby te państwa, które dobrowolnie chciałyby przystąpić do unii bankowej (Jurkowska-Zeidler, 2016).

W latach 2017-2019 miał miejsce trzyletni etap reasekuracji. Jego celem było osłabienie relacji bank-rząd tak, aby banki stały się bardziej niezależne. Wówczas systemy gwarancji depozytów poszczególnych państw uzyskają dostęp do EDIS dopiero w momencie wyczerpania środków własnych, a dodatkowym warunkiem jest konieczność zachowania zgodności z Dyrektywą 2014/49/UE (2014). Celem drugiego etapu (lata 2020-2023) $\mathrm{w}$ ramach co-insurance jest przekształcenie systemu w taką instytucję, której celem jest uwspólnienie. Zabieg taki będzie skutkował brakiem obowiązku krajowego systemu gwarantowania depozytów do wyczerpania środków własnych, zanim uzyska dostęp do 
środków EDIS. W przypadku, gdyby zaistniała sytuacja konieczności częściowej wypłaty na rzecz deponentów, środki te byłyby dostępne natychmiastowo. Planowane jest, by początkowo niskie wkłady EDIS, osiągnęły poziom $80 \%$. Wiąże się to z wyższym uwspólnionym ryzykiem między krajowymi systemami przez EDIS. Planowane jest zapewnienie pełnego ubezpieczenia krajowych systemów gwarancji depozytów do 2024 r. przez EDIS, które oscylować będą na poziomie $0,8 \%$ wartości depozytów gwarantowanych, zgromadzonych w bankach państw uczestniczących w unii bankowej. W 2024 r. dodatkowo ma zostać $w$ pełni utworzony Jednolity Fundusz Restrukturyzacyjny i Uporządkowanej Likwidacji, który tworzą Jednolita Rada ds. Restrukturyzacji i Uporządkowanej Likwidacji, Rada, Komisja i organy ds. restrukturyzacji i uporządkowanej likwidacji uczestniczących państw członkowskich (Rozporządzenie nr $806 / 2014,2014)$. Ma ona na celu zadbać o prawidłowe przeprowadzenie restrukturyzacji i uporządkowanej likwidacji banków, a także zapewnić właściwe stosowanie przepisów odnoszących się do tych procedur w strefie euro i innych państwach członkowskich, które przystąpiły do programu unii bankowej1 (Jednolita Rada ds. Restrukturyzacji i Uporządkowanej Likwidacji, 2014).

Mechanizm zabezpieczenia jest taki sam, jak na etapie koasekuracji, z tą jednak różnicą, że EDIS zapewni pełne pokrycie. Finansowanie funduszu gwarantowania depozytów opierać ma się na finansowaniu ze składek ex ante. Składki te pochodzą bezpośrednio od banków, które płacą je Jednolitej Radzie. Co ważne, składki mogą podlegać rekompensacji (Jurkowska-Zeidler, 2016). Fundusz gwarantowania depozytów ma być finansowany ze składek ex ante, które są należne i płacone przez banki bezpośrednio Jednolitej Radzie. Jednolita Rada ma prawo zarządzać dwoma funduszami

Unia bankowa powstała jako odpowiedź na kryzys finansowy z $2008 \mathrm{r}$. Tworza ją: jednolity mechanizm nadzorczy oraz jednolity mechanizm restrukturyzacji. Ten pierwszy obejmuje bezpośrednim nadzorem na szczeblu europejskim największe i najważniejsze banki w strefie euro. Celem jednolitego mechanizmu restrukturyzacji i uporządkowanej likwidacji jest dokonanie upadłości banków w sposób uporządkowany, jak najmniej obciązający podatników i gospodarkę jednocześnie tj.: funduszem gwarantowania depozytów (deposit insurance fund, DIF) i funduszem restrukturyzacji (single resolution fund, SRF). Dzięki temu utworzone zostanie współdziałanie w zakresie łączenia obowiązków na płaszczyźnie restrukturyzacji i uporządkowanej likwidacji, a także gwarantowania depozytów (Waliszewski, 2016). Składki na tym etapie w 2014 r. miały być oparte na ocenie ryzyka. Składki te banki państw biorących udział w unii bankowej opłacają na rzecz macierzystych funduszy gwarantowania depozytów. Składka obliczana jest przez uczestniczący system gwarantowania depozytów, biorąc pod uwagę jego wszystkie inne banki. $\mathrm{W}$ związku z tym etap reasekuracji pozwolić miał na ograniczenie negatywnego sprzężenia zwrotnego $w$ relacji bank-rząd, jednak nie jest on w stanie zapewnić jednakowej ochrony wszystkich depozytów w ramach unii bankowej (Jurkowska-Zeidler, 2016).

Kolejnym etapem wdrażania EDIS ma być koasekuracja, która ma potrwać cztery lata. Od 2020 r. system reasekuracji ma rozpocząć swoje przekształcanie w system uwspólnienia. Jak wspomniano, różnicą między systemami byłoby to, że krajowe system gwarantowania depozytów nie byłyby zobligowane do wyczerpania środków własnych przed skorzystaniem $z$ możliwości pomocy finansowej ze strony EDIS. Środki te byłyby dostępne od razu, gdy tylko zaistniałaby konieczność pokrycia przez krajowe systemy zabezpieczeń depozytów wypłat na rzecz deponentów lub przymusowej restrukturyzacji (Narodowy Bank Polski, 2015). Na tym etapie Jednolita Rada będzie uprawniona do ściągania od banków powiązanych z uczestniczącymi systemami gwarantowania depozytów nadzwyczajnych składek ex post, w chwili, gdy środki dostępne w funduszu systemu gwarantowania depozytów nie będą na tyle wysokie, aby pokryć straty. Po tym czteroletnim etapie wszystkie krajowe systemy krajowych zabezpieczeń depozytów przejdą pod ochronę EDIS i to on będzie je w pełni zabezpieczać (nastąpić ma to w 2024 r.). Całkowite zabezpieczenie wiąże się z pełnym finansowaniem zapotrzebowania płynności oraz będzie pokrywać wszystkie straty, 
które są skutkiem wypłat lub wkładu na rzecz restrukturyzacji i uporządkowanej likwidacji. Działanie systemów opiera się na identycznym działaniu, jak na etapie koasekuracji, jednak EDIS zapewnić ma pełne pokrycie zobowiązań. Naczelną zasadą, jaką się kierowano jest to, że EDIS, bez względu na etap, nie może, a raczej nie powinien podwyższać łącznych kosztów dla sektora bankowego przyrównując do obecnych zobowiązań na podstawie Dyrektywy 2014/49/UE (2014). EDIS swoimi działaniami ma w efekcie podnieść jakość ekonomiczną już istniejących mechanizmów gwarantowania depozytów w unii bankowej przez stopniowe łączenie dostępnych środków w przypadku, gdy zaistnieje potrzeba dokonania wypłat bez konieczności ogólnego wzrostu składek ze strony banków. Składki, które banki wpłacą na EDIS zostaną odliczone od ich składek, które wpłacają na rzecz systemów gwarantowania depozytów w państwie macierzystym. W dalszym etapie proporcja miedzy wpłatami składek na rzecz EDIS a składkami na rzecz systemów krajowych będzie ulegać zmianie. Te pierwsze będą wzrastać, a te drugie będą obniżane. EDIS zostanie skonstruowany następująco: będzie bazował na dwóch poziomach, $z$ czego jeden będzie jednolitym zbiorem przepisów (Dyrektywa 2014/49/ UE (2014)), a drugi poziom będzie opierał się na właściwym EDIS, obowiązkowym dla wszystkich państw członkowskich strefy euro i otwarty dla państw spoza tej strefy (Borsuk i Klupa, 2017).

Co ciekawe nie udało się w czasie zrealizować tych założeń, a dodatkowo w 2017 r. zrezygnowano $z$ etapu koasekuracji. Stało się tak dlatego, że nie osiągnięto $\mathrm{w}$ pełni zamierzonych efektów ze względu na różnice, jakie występują w poszczególnych państwach. Spowodowało to wydłużenie procesu tworzenia EDIS i zmianę zasad, według których miał funkcjonować. Etap wdrażania EDIS miał być dwuetapowy składający się z etapu reasekuracji i etapu pełnego zabezpieczenia. Etap reasekuracji ma trwać minimum 5 lat, a wspólny fundusz byłby wykorzystywany wyłącznie jako wsparcie płynności dla uczestniczących DGS. Limit środków ma zostać zwiększony stopniowo z 20\% do 100\%. Etap ten nie będzie pokrywał strat, jakie poniosły krajowe systemy gwarantowania depozytów. Ryzyko odnoszące się do każdego rodzaju wsparcia ograniczałoby się więc do relacji krajowy system gwarantowania depozytów-wspólny fundusz, bez przenoszenia na inne krajowe systemu gwarantowania depozytów (Lipiński, 2019).

Natomiast etap pełnego zabezpieczenia opierałby się na całkowitym pokrywaniu potrzeb płynnościowych ze wspólnego funduszu. Dodatkowo straty ponoszone przez biorące udział $\mathrm{w}$ programie krajowe systemy gwarantowania depozytów byłyby przejmowane i rozdzielane na wszystkie systemy gwarantowania depozytów. W celu przejścia do drugiego etapu należy spełnić wiele warunków, aby zminimalizować ryzyko oraz wyrównać skalę zagrożeń dla funkcjonowania instytucji kredytowych. Jedną z zasad jest korzystanie $z$ asekuracji EDIS tylko przez członków, którzy we własnym zakresie zgromadziliby środki stanowiące określoną wartość środków gwarantowanych: od minimum $0,05 \%$ do $0,4 \%$ (maksymalny poziom ma być podany 3 lipca 2024 r.). Bez zmian pozostać ma zwrot przez krajowe systemy gwarantowania depozytów do wspólnej kasy kwoty finansowania uzyskanego, jako forma wypełnienia luki płynności, która pomniejszona odpowiednio będzie o kwotę pokrycia strat przez EDIS. Wysokość środków wnoszonych do wspólnego funduszu stanowić powinna połowę kwoty, która wynika $z$ minimalnego docelowego poziomu zabezpieczenia depozytów (wysokość jest oznaczona w Dyrektywie 2014/49/UE (2014)). Środki te rozdzielone byłyby na dwa subfundusze: indywidualny i wspólny. Z czego składki na subfundusz wspólny wyznaczone byłyby przez stosunek udziału poszczególnych systemów gwarantowania depozytów w łącznej kwocie depozytów gwarantowanych. Miałoby to nastąpić w odrębnym akcie prawnym. Natomiast składki indywidualne ustalone zostałyby przez systemy gwarantowania depozytów, biorąc pod uwagę ich udział w łącznej kwocie depozytów gwarantowanych oraz oceny ryzyka poszczególnych instytucji (Lipiński, 2019). 


\section{Zakończenie}

Europejski system gwarantowania depozytów wydaje się być koniecznym w celu budowy pełnej unii bankowej i doprowadzenia do zwiększenia integracji państw strefy euro. Przeniesienie odpowiedzialności i finansowania depozytów z poziomu krajowego na europejski spowoduje, że w przypadku upadłości banków z państwa, który ma problemy, będzie dokonywany podział środków finansowych od systemów bankowych, które są dobrze nadzorowane i banków dobrze zarządzanych. $Z$ perspektywy Polski, która obecnie nie planuje przystąpić dobrowolnie do unii bankowej na zasadzie „bliskiej współpracy”, a tym samym nie przystąpi do europejskiego systemu gwarantowania depozytów, proces wdrażania trzeciego filaru nie wpłynie znacząco na BFG. Warto dodać, że proces wdrażania trzeciego filaru unii bankowej korzystnie wpłynie na zwiększenie bezpieczeństwa Polski, bo otoczona zostanie państwami, które będąc $w$ strefie euro są obligatoryjnie związane koniecznością przystąpienia do programu. W ramach unii bankowej najważniejszym wydaje się zapewnienie kooperacji instytucji zaangażowanych $\mathrm{w}$ zapewnienie stabilności finansowej i ochronę depozytów. Utworzenie europejskiego systemu gwarantowania depozytów wzmocni ochronę deponentów, ponieważ odtąd odpowiedzialność przeniesiona zostanie na poziom europejski.

\section{Bibliografia}

BFG. (2019). Raport roczny 2019. Pobrano 20.12.2020 z https://www.bfg.pl.

Boccuzzi, G. (2016). The European banking union: supervision and resolution. Houndmills: Palgrave Macmillan. doi:10.1057/9781137555656.

Borsuk, M., i Klupa, K. (2017). Europejski system gwarantowania depozytów (EDIS) jako trzeci filar unii bankowej i jego wpływ na państwa spoza strefy euro: perspektywa Polski. Zarzadzanie $i$ Finanse. Journal of Management and Finance, 15(1).
Cariboni, J., Branden, K., Campolongo, F., i De Cesare, M. (2008). Deposit protection in the EU: state of play and future prospects. Journal of Banking Regulation, 9(2). doi:10.1057/jbr.2008.2.

Dunaszewska, A. (2009). Podstawowe zasady gwarantowania depozytów w systemie słowackim. Bezpieczny Bank, 1(38).

Dyrektywa 94/19/WE Parlamentu Europejskiego i Rady z dnia 30 maja 1994 r. w sprawie systemów gwarancji depozytów (OJ L 135, 31.5.1994).

Dyrektywa Parlamentu Europejskiego i Rady 2009/14/WE z dnia 11 marca 2009 r. zmieniająca dyrektywę 94/19/WE w sprawie systemów gwarancji depozytów w odniesieniu do poziomu gwarancji oraz terminu wypłaty (OJ L 68, 13.3.2009).

Dyrektywa Parlamentu Europejskiego i Rady 2014/49/UE z dnia 16 kwietnia 2014 r. w sprawie systemów gwarancji depozytów (OJ L 173, 12.6.2014).

Florczak, T. (2015). Funkcjonowanie systemów gwarancji depozytowych na przykładzie Polski i Czech. Finanse i Prawo Finansowe, 2(37).

Jednolita Rada ds. Restrukturyzacji i Uporządkowanej Likwidacji: Ogłoszenie o naborze na stanowisko: Przewodniczący Jednolitej Rady (COM/2014/10359, Dz.U. C 217A $z$ 10.7.2014)

Jurkowska, A. (2018). Uwarunkowania regulacyjne prowadzenia działalności przez banki spółdzielcze w Polsce. Bezpieczny Bank, 3(72). doi: 10.26354/bb.3.3.72.2018.

Jurkowska-Zeidler, A. (2016). Europejski system gwarantowania depozytów: trzeci brakujący filar do dokończenia unii bankowej. Annales Universitatis Mariae Curie-Skłodowska, Sectio H: Oeconomia, 50(4). doi:10.17951/h.2016.50.4.171.

Komisja Europejska. (2012). Nowe środki zarzadzania $w$ sytuacjach kryzysowych maja $w$ przyszłości zapobiec konieczności ratowania banków. Pobrano 20.12.2020 z https://ec.europa.eu.

Lipiński, C. (2019). Tworzenie europejskiego systemu gwarantowania depozytów. Bezpieczny Bank, 1(74). doi:10.26354/bb.2.1.74.2019.

Litan, R. (2007). What should banks do? Waszyngton: The Brooking Institution.

Małecka, E., i Włodarczyk, B. (2012). Systemy gwarantowania depozytów: konwergencja rozwiązań stosowanych w krajach Unii Europejskiej. Zarzadzanie $i$ Finanse. Journal of Management and Finance, 4(1). 
Narodowy Bank Polski. (2015). Przegląd spraw europejskich. Pobrano 20.12.2020 z https://www. nbp.pl.

Ognjenovic, D. (2017). Deposit insurance schemes: funding, policy and operational challenges. Cham: Palgrave Macmillan. doi:10.1007/978-3-319-51143-6.

Parlament Europejski. (2020). Polityka $w$ dziedzinie ustug finansowych. Pobrano 20.02.2020 z lokalizacji https://www.europarl.europa.eu.

Pawlikowski, A. (2005). Problemy, zakres i kryteria wyboru w kształtowaniu systemu gwarantowania depozytów w świetle teorii i doświadczeń międzynarodowych. Bezpieczny Bank, 2(27).

Rozporządzenie Ministra Finansów z dnia 22 lutego 2019 r. w sprawie zawieszania wypłaty środków gwarantowanych deponentom w przypadku blokady środków zdeponowanych na rachunku (Dz.U. 2019 poz. 389).

Rozporządzenie Parlamentu Europejskiego i Rady (UE) nr 806/2014 z dnia 15 lipca 2014 r. ustanawiające jednolite zasady i jednolitą procedurę restrukturyzacji i uporządkowanej likwidacji instytucji kredytowych i niektórych firm inwestycyjnych $w$ ramach jednolitego mechanizmu restrukturyzacji i uporządkowanej likwidacji oraz jednolitego funduszu restrukturyzacji i uporządkowanej likwidacji oraz zmieniające rozporządzenie (UE) nr 1093/2010 (Dz.U. L 225 z 30.7.2014).

Szczepańska, O. (2005). Podstawowe przesłanki, założenia i struktura sieci bezpieczeństwa finansowego w świetle teorii i doświadczeń międzynarodowych. Bezpieczny Bank, 1(26).
Ustawa z dnia 14 grudnia 1994 r. o Bankowym Funduszu Gwarancyjnym (Dz.U. 1995 nr 4 poz. 18).

Ustawa z dnia 17 stycznia 2019 r. o zmianie ustawy o Bankowym Funduszu Gwarancyjnym, systemie gwarantowania depozytów oraz przymusowej restrukturyzacji oraz niektórych innych ustaw (Dz.U. 2019 poz. 326).

Ustawa z dnia 29 sierpnia 1997 r. Ordynacja podatkowa (Dz.U. $1997 \mathrm{nr} 137$ poz. 926).

Waliszewski, K. (2016). Europejski system gwarantowania depozytów jako trzeci filar unii bankowej. Bezpieczny Bank, 1(62).

Wniosek Rozporządzenie Parlamentu Europejskiego i Rady zmieniające rozporządzenie (UE) nr 806/2014 w celu ustanowienia europejskiego systemu gwarantowania depozytów (COM/2015/0586).

Zalecenie Komisji 87/63/EWG z dnia 22 grudnia 1986 r. dotyczące wprowadzenia systemów gwarancji depozytów we Wspólnocie (OJ L 033 04/02/1987).

\section{Informacje uzupełniające}

Wkład autorski: autor zaakceptował ostateczną wersję artykułu.

Źródła finansowania: artykuł został w całości sfinansowany ze środków własnych autora.

The deposit insurance system in the European Union

\begin{abstract}
Motivation: There is a lot of information on the banking union in the literature on the subject. However, there is no indication of the features of the European deposit guarantee scheme, taking into account changes after 2017.

Aim: The aim of the article is to present the problem of the deposit guarantee system in the European Union, taking into account the deposit guarantee systems in the Member States. Its assumptions and stages of introduction were described. The new reform, which was caused by the lack of timely implementation of the original assumptions of individual stages and its changes were also discussed. Moreover, basic information about the Bank Guarantee Fund (BGF) was also included.

Materials and methods: Critical analysis of the literature on the subject was chosen as the research method and statistical data were used. The empirical material is the BGF data and data included in publications.

Results: The European deposit guarantee system seems to be necessary in order to build a full banking union and lead to greater integration of the euro area countries. The creation of a European deposit insurance scheme will strengthen the protection of depositors, as responsibility will henceforth be transferred to the European level.

Keywords: European deposit insurance scheme; Bank Guarantee Fund; banking union

JEL: G21; G28; G29, G33
\end{abstract}


